\title{
Renewable Energy Engineering Technology (REET) Program
}

\section{Dr. Alireza Kavianpour, DeVry University, Pomona}

Dr. Alireza Kavianpour received his PH.D. Degree from University of Southern California (USC). He is currently Senior Professor at DeVry University, Pomona, CA. Dr. Kavianpour is the author and co-author of over forty technical papers all published in IEEE Journals or referred conferences. Before joining DeVry University he was a researcher at the University of California, Irvine and consultant at Qualcom Inc. His main interests are in the areas of embedded systems and computer architecture. 
New title for the paper: Renewable Energy Engineering Technology (REET) Program

\begin{abstract}
REET program exposes students to the world of creating and implementing green technologies, such as wind, solar, photovoltaics, geothermal, and biomass power. A four-year degree with a specialization in renewable energy preparing student with technology skills that can put them to work in green technologies across three areas: Engineering Technology, Information Technology, and Software and Information Systems. There is an international demand for renewable energy technology. As an example, in Australia, growth in demand for engineers and technicians in the renewable energy sector is tripled between 2008 and 2020.

There are some universities offering four years degree in the field of Renewable Energy Engineering Technology (REET). In this paper author's experience in teaching courses in REET program, typical student senior projects, and job market forecast for this field will be discussed. The assessment data for the REET senior project was analyzed. Several recommendations for improving student's outcomes are suggested.
\end{abstract}

\title{
1- Introduction
}

Why Study Alternative/Renewable Technologies?

Alternative energy is referring to sources of energy that replace fuel sources without the undesired consequences. Fossil fuel burning produces pollution. Nuclear power is a common alternative to fossil fuels however, radiation and the long-term containment cause great concern and expense. Wind power would be an example of an alternative to nuclear power. It is also a renewable energy source. Renewable energy comes from natural resources such as sunlight, wind, tides, geothermal heat ${ }^{1,2,3}$.

There is an increasing recognition that future energy sustainability is one of the major issues of the 21 st century. It is not only critical for the United States, but also important for the rest of the world. There is a great sense of urgency for alternative energy sources (wind, solar, ocean power, etc.) over conventional fossil fuel.

Fossil fuels do not only power our cars, but many power plants rely on them as well. What about the environment? Climate change is one of the key challenges facing us worldwide. Global warming, mainly caused by the burning of fossil fuels, is made worse by the inefficient use of energy that could push the ecosystem into a disastrous state of failure. And, of course, there are 
nuclear power plant hazards ${ }^{1,4}$.

Figure 1 illustrates energy consumption in different parts of the world ${ }^{1}$. Their success is closely related to the types and quantities of energy resources exploited, as well as the efficiency of conversion of a particular type energy into work and heat.

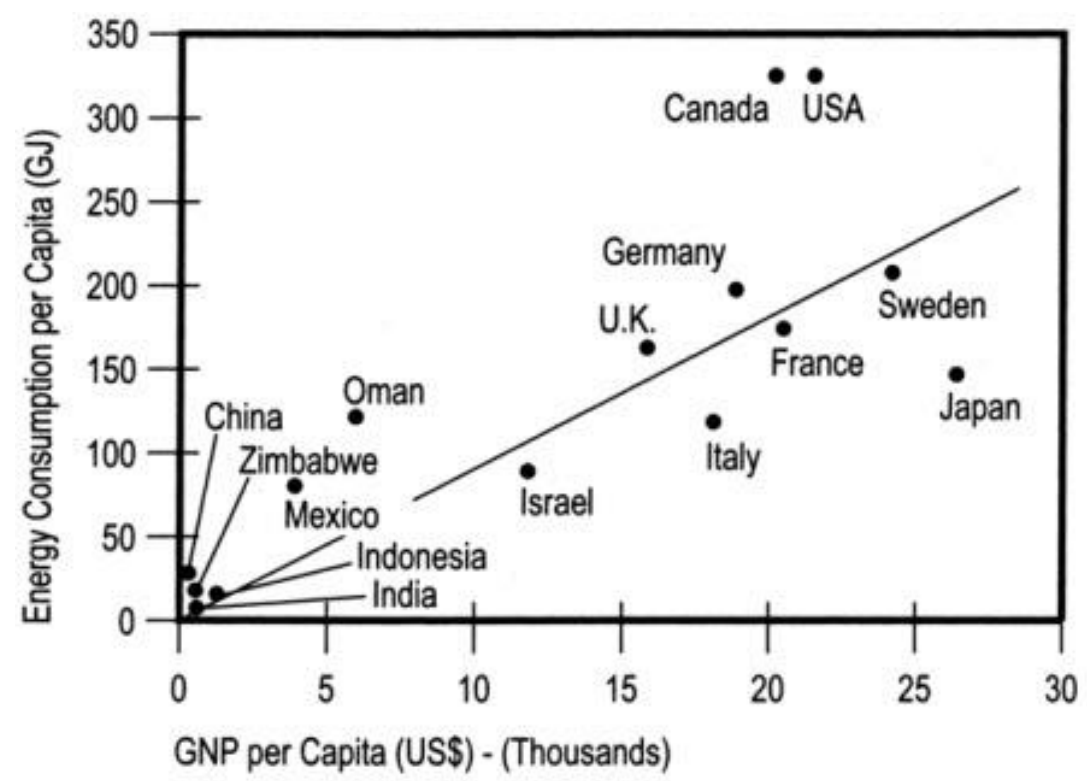

Figure 1. Energy consumption in different parts of the world

\section{2- REET Program}

REET is a renewable energy education program exposes students to the exciting world of creating and implementing green technologies, such as wind, solar, geothermal, and biomass power ${ }^{5}$. A bachelor's degree with a specialization in renewable energy offers focused engineering technology coursework, preparing students with technology skills that can put to work future in green technologies across three areas: Engineering Technology, Information Technology, and Software and Information Systems.

As student pursue a bachelor's degree with a specialization in renewable energy, will learn about alternative energy generation and the complex factors behind green technology. This includes how economics, sociology and environmental science are connected, and the design processes used in today's leading renewable energy initiatives. From planning and project management to energy production and storage.

In the following, courses for this program are listed. Items (a) though (h) are more or less similar to Electronics Engineering Technology (EET) program and there is no need to cover them here. However, items (j) and (k) will be explained in detail. 
Courses in REET program include:

(a)- COMMUNICATION SKILLS

(b)- HUMANITIES, SOCIAL SCIENCES

(O- MATHEMATICS AND NATURAL SCIENCES

(d)- PERSONAL AND PROFESSIONAL DEVELOPMENT

(e)-TECH CORE COURSES

(f)- AUTOMATION AND ELECTRICAL SYSTEMS

(g)- INFORMATION SYSTEMS AND PROGRAMMING

(h)- APPLICATION DEVELOPMENT

(i)- TECHNOLOGY CAREER PREPARATION

(j)- SENIOR PROJECT

(k)-SPECIALIZED COURSES

In the following, specialized courses in REET program will be addressed.

REET 100 Alternative Energy Technologies with Lab

This course is designed as an introduction to renewable energy technologies. Concepts of energy sources and systems to be surveyed include solar/photovoltaic, wind power, fuel-cells, hydroelectric, the smart grid, alternative fuels, geothermal power, ocean, nuclear, and biofuels. Energy conversions from these various sources will be examined and applications explored. Socio-economic, environmental, and regulatory issues will also be considered. Labs will be used to explore key aspects of alternative and renewable power sources.

REET 150 Power Electronics and Alternative Energy Applications with Lab

This course covers power switching circuits such as rectifiers, AC-DC and DC-DC converters, inverters and motor drives. Power semiconductor devices, thermal management, efficiency and power electronics applications are emphasized. Lab projects involve simulation and construction of power electronic circuits needed to convert power derived from both conventional systems and alternative energy sources such as solar and wind.

REET200 Electric Machines \& Power Systems w/Lab 
This course is a study of electric machines and power systems with an emphasis on renewableenergy applications. Topics include three-phase circuits, power-factor correction, transformers, synchronous machines, dc motors, induction motors, power-system transmission and distribution, and an introduction to power-flow studies. Lab projects involve the simulation and construction of the machines necessary for the transmission of power.

REET 250 Renewable Energy: Science, Technology, and Management

This course introduces science and technology behind renewable energy technology while considering business decisions required to invest in and manage systems using this technology. Among others, solar technologies, fuels synthesized from biomass, hydrogen and wind are explored.

REET 300 Sustainability Management and Administration

This course looks at aspects of the operations function for its role in managing a sustainable organization. Planning, supportive information systems, compliance management, the sustainable supply chain, sustainability applied to human resources, and other sustainable system elements managed and controlled by operations are considered.

\section{REET 350 Sustainability Operations}

This course explores the management and administration of an organization's commitment to long-term sustainability. Course material examines the trade-offs between individual decisions of economic utility and production value associated with costs and return on investment and consideration of the impacts on the environment and society as a whole.

\section{REET 400 Sustainability Marketing}

This course analyzes marketing functions from a perspective of sustainable practices. Opportunities to develop products pricing, channels, promotion, and markets are considered as they relate to maximizing producer and consumer value with attention to societal and environmental considerations.

\section{3- Job opportunity in REET}

Industry experts say there should be plenty of engineering jobs in renewable energy to go around in the next few years, and they will be well paying and long lasting. There is already a hiring activities in solar energy companies. Start-ups in fast-growing areas of active research such as thin-film solar and concentrating solar are creating stable jobs for renewable energy technology engineers. There's room for hundreds of engineers on the R\&D side, and those jobs are in Europe and the Middle East as well. According to Payscale.com in August 2019, the national median annual salary for energy engineers working in renewable energy was $\$ 71,370$. 
Renewable energy production is growing which will lead to increased job opportunities. According to the U.S. Bureau of Labor Statistics (BLS), wind energy is the fastest-growing source of energy and could contribute $20 \%$ of the nation's electricity by 2030. Solar and hydropower are making less significant contributions but also have potential for growth.

According to the American Society of Mechanical Engineers, the employment opportunities for renewable energy engineers can be dictated by several factors. Developing the supply lines and facilities for renewable energy is expensive and requires government subsidies. Some forms of energy are only available in the certain regions while others may be expensive to convert or require the assembly of large machines.

\section{4- Topics for Senior Project}

Student in REET major could have their senior project in the following area:

(a)-Wind

The wind power capacity grew 39 percent since 2004 and is expected to continue growing rapidly ${ }^{1}$. Occupations in this field are all related to the manufacturing, project development, operation and maintenance, of turbines and wind farms. Careers include scientists, engineers, and engineering technicians to design and test turbines. Machinists, computer-controlled machine tool operators, assemblers, welders, quality-control inspectors, and industrial production managers help to produce turbines ${ }^{6,7,8}$.

(b)- Hydro

Oldest and largest source of renewable energy is water. Water power has vast potential and is available in every region. It is estimated that by $2025,140,000-440,000$ new jobs will be created by hydropower in the U.S.

One of the most common and recognized types of these systems is the hydropower dam utilizes the water to generate electricity in a penstock and turbine configuration. A penstock is a method of conveying water from one area to another, taking advantage of elevation differences between the two areas to create pressure at the destination for the turbine.

\section{(C)-Biomass}

Biofuels made from biomass, including biodiesel and ethanol, are in demand.

The industry needs biochemists, biophysicists, chemists, and microbiologists to find better ways to create biofuels.

(d)- Solar Energy and Black Body Radiation

The Sun is an excellent source of energy and it radiates energy in all directions, but only a small fraction is received on Earth because of our size and distance from the Sun. Capture of sunlight 
energy in solar panels and its conversion to electricity and heat are the basis of solar energy or solar power.

Photovoltaics (PVs), or solar cells, generate electrical power via the conversion of solar radiation into dc electricity. They are semiconductor devices with the photovoltaic effect. The demand for renewable energy sources has resulted in a considerable increase in the research, development, and manufacturing of solar cells and arrays. Figure 2 illustrates the Solar Panel configuration ${ }^{1}$.

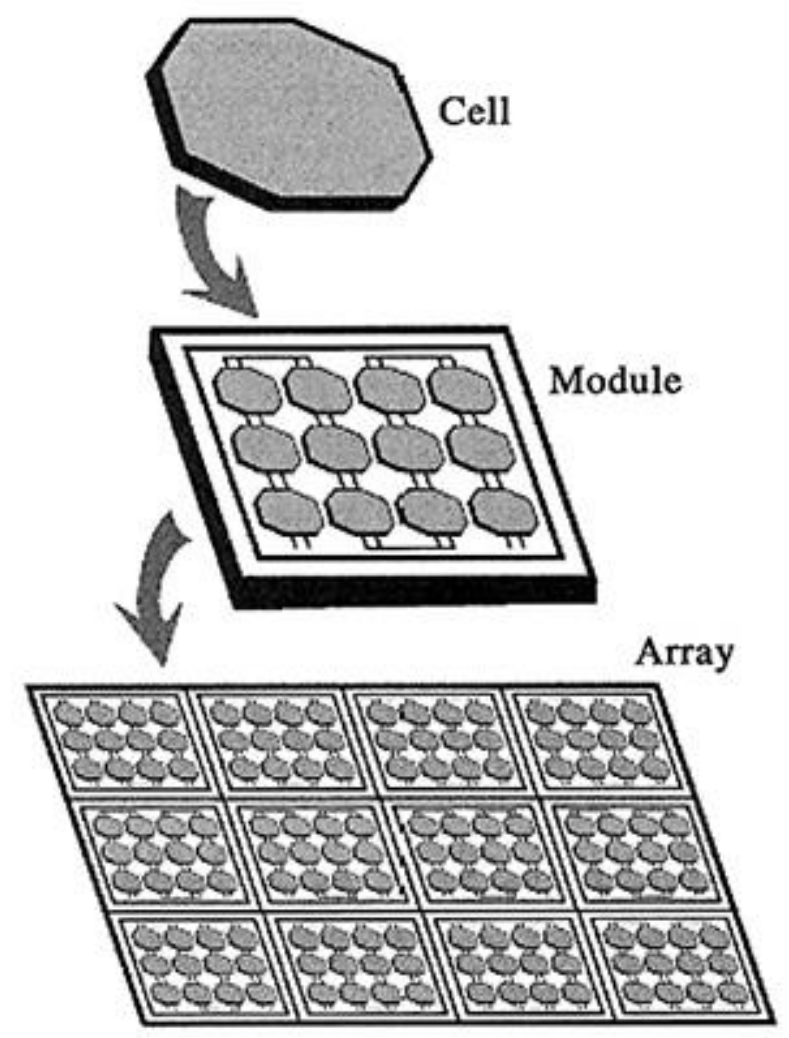

Figure 2: Solar Cell, Module and Panel

A photovoltaic cell transforms energy provided by the Sun into electric energy using the photovoltaic effect. The solar cells are made of semiconductor materials that form a P-N junction and act like a diode. When solar light, in the form of photons, strikes the cell, the electrons in the outer shell of the silicon atoms are moved by the electric field to the N-type layer. At the same time, for each free electron, there is a hole that moves to the P-type layer ${ }^{9,10}$.

(e)- Geothermal Sources 
There are four main categorizations of geothermal sources, and they include hydrothermal, geopressured, magma, and enhanced geothermal. Each source has advantages and disadvantages associated with the gathering and distribution of the energy.

Hydrothermal sources are found in areas where water is heated by permeable rock and either gathered in a liquid state or vaporized into steam. They are considered to be the best resource for geothermal power and the subsequent generation of electricity. While power plants associated with this source currently exist, the type of rock formations needed are rare, and the trapped gases released can form acids and present a hazard to both the plant equipment and the environment ${ }^{1}$.

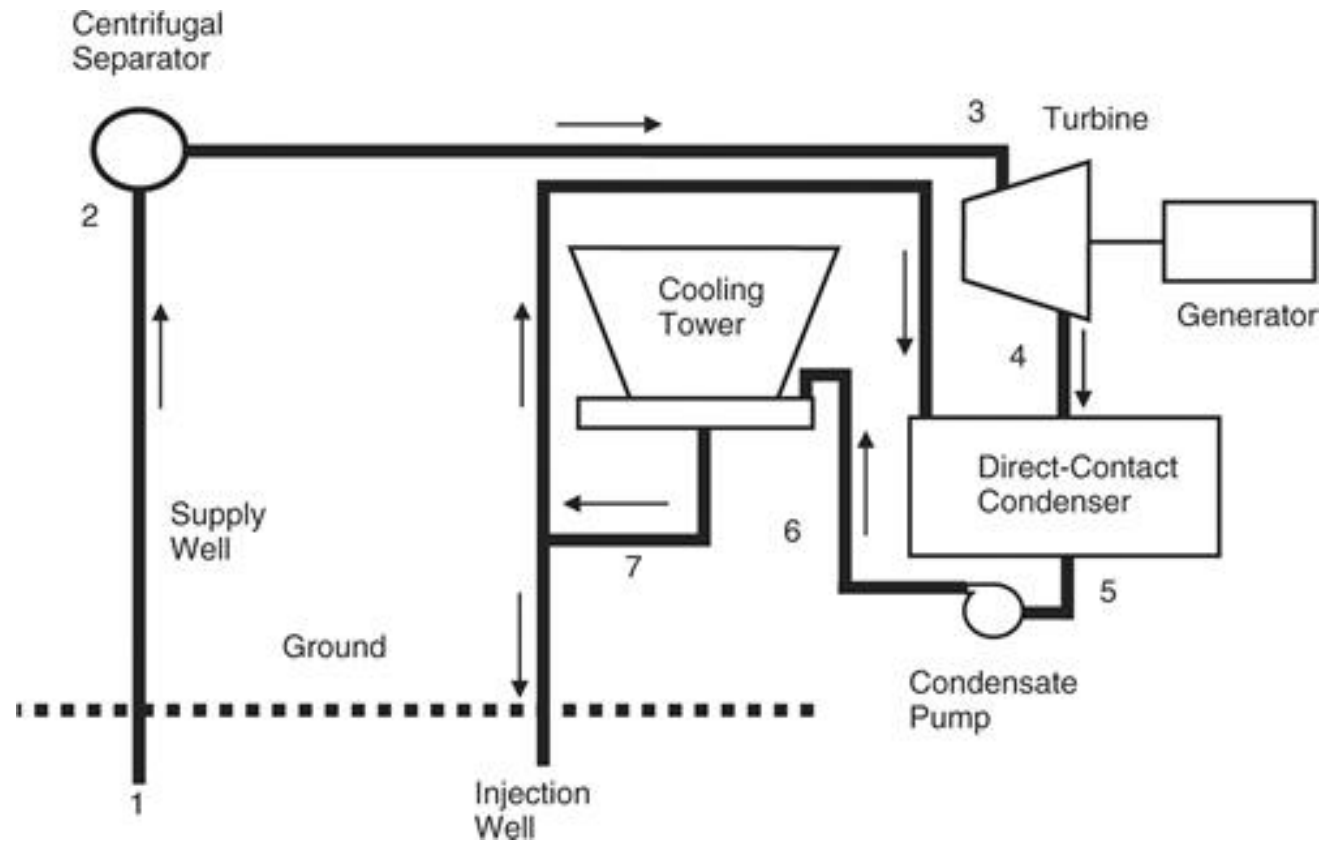

Figure 3: Vapor-Dominated System

\section{(f)- Ocean Energy}

Energy extraction from the ocean can take three major forms: temperature, tidal, and wave. The first, regarding temperature, is referred to as ocean thermal energy conversion (OTEC) and involves the variation between the temperature on the surface of the ocean that has been solar heated and the temperature at a greater depth typically at 1,000 meters.

There are two types of OETC systems: closed loop and open loop. The differences between the two systems directly correlate with the medium utilized in the evaporator. With an open system utilizing the Claude cycle named after the inventor of the first OETC system to be deployed, the ocean surface water is sent to the evaporator, with the resulting steam sent to the turbine to generate electricity. Because of the volume of the turbine-working fluid, typical steam turbines cannot be deployed for an open system. A closed loop system utilizes ammonia and propane as 
the working fluid, and with the surface water providing the energy to vaporize the working fluid and exiting the turbine, the fluid is condensed and sent back through the cycle ${ }^{\mathbf{1}}$.

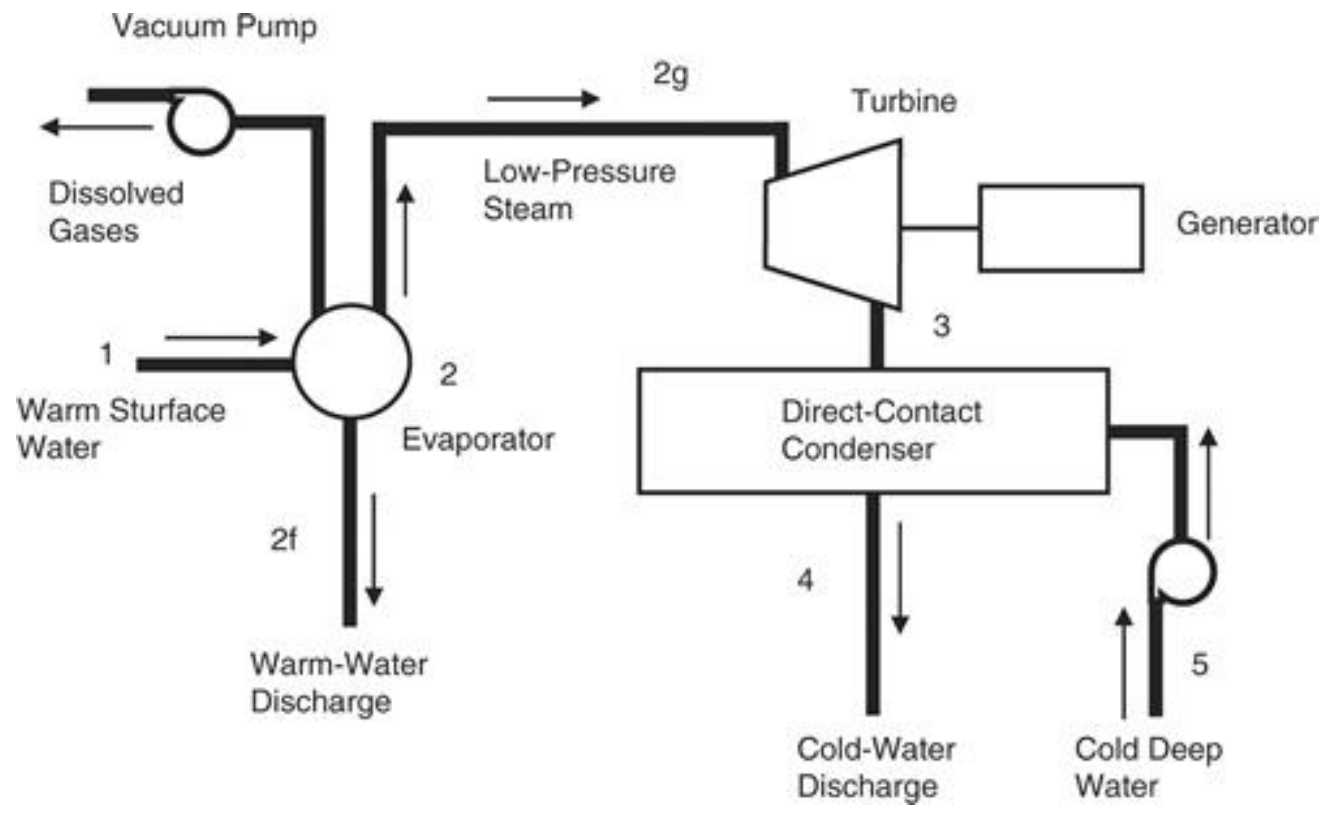

Figure 4: Open OETC System

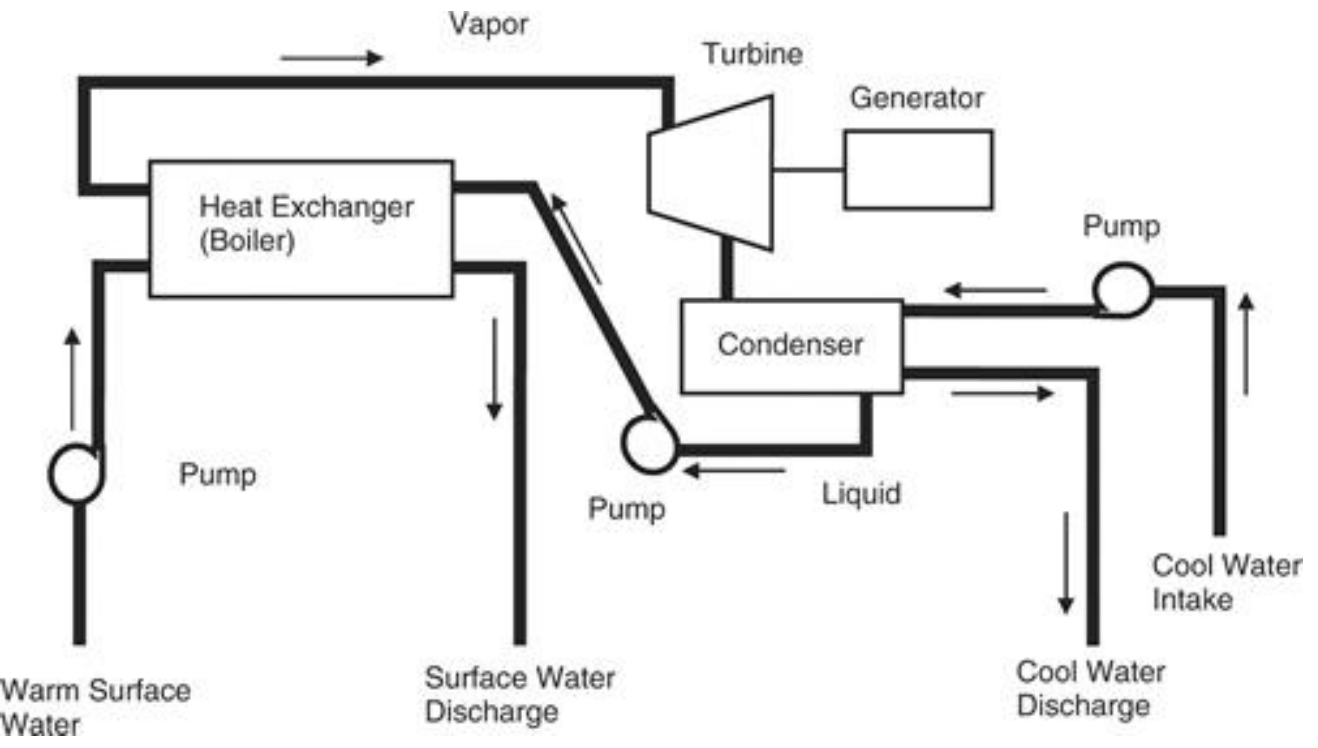

Figure $5^{1}$ : Close OETC System

\section{(h)- Fuel Cells}

Fuel cells are devices that generate electricity through the provision of fuel. While analogous to fuel combustion-based systems and batteries, fuel cells are different in that the generation of electricity is not bound by the exhaustion of the source of fuel or chemically stored energy. Fuel 
cells will continue to function as long as there is a fuel source applied. As with combustion systems, fuel cells produce energy and heat, but are not considered heat engines and are more efficient than conventional heat-engine systems.

The fuel cell is comprised of three main components: anode, electrolyte, and cathode. Hydrogen is a typical source of fuel for the cell. The reaction at the anode as the fuel is introduced produces ions and free electrons. The electrons pass through the conductive elements between the anode and cathode, resulting in current flow through a load while the ions combine with introduced oxygen and emerge as water from the system ${ }^{12,13,14}$.

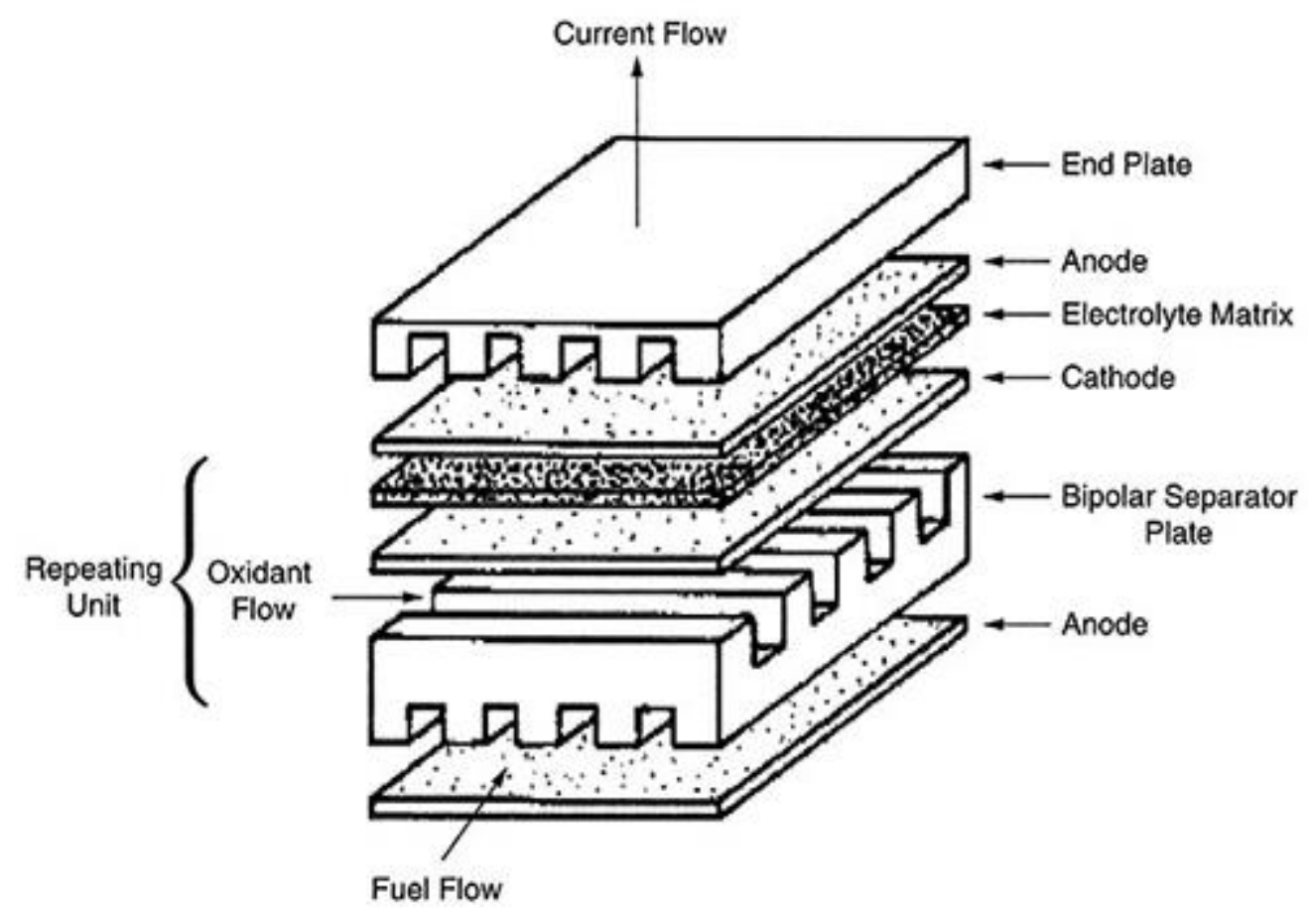

Figure 6: Fuel Cell Stack

\section{(5)-Student Senior project}

In this section several senior projects by REET students will be discussed.

\section{Project 1}

\section{Solar Powered Water Well}

\section{Objective}

An Arduino Microcontroller will be programmed to rotate the solar grid with the angle of the sun to optimize sunlight exposure. The solar cells will charge $12 \mathrm{~V}$ battery packs in the well housing. 
A pressure switch will sense when there is a decrease in the pressure in the water lines or pressure tank (i.e. someone showers or turns on a faucet) and will automatically recharge the well water. This automatic pump will be powered by the $12 \mathrm{~V}$ battery packs that have been charged by the solar panel.

\section{Applications}

This project has many applications by expanding on the initial well system. sprinkler systems and irrigation systems could be fed from these wells. Also, the well system could be used as a back-up water supply in areas hit with natural disasters and could also be used in areas that do not have electricity. Another option is to attach a water heater to have a completely solar powered water supply at all temperatures. Figures 7, 8, and 9 display the block diagram, operation and the circuit of this project.

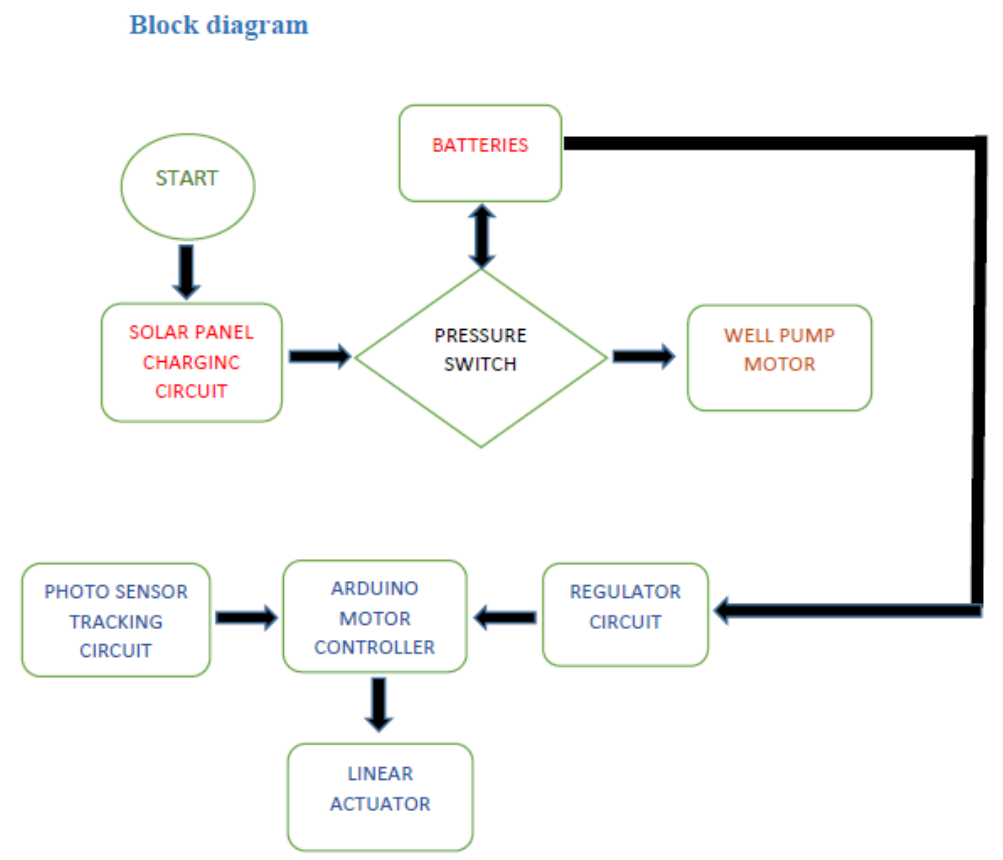

Figure 7: Block Diagram 


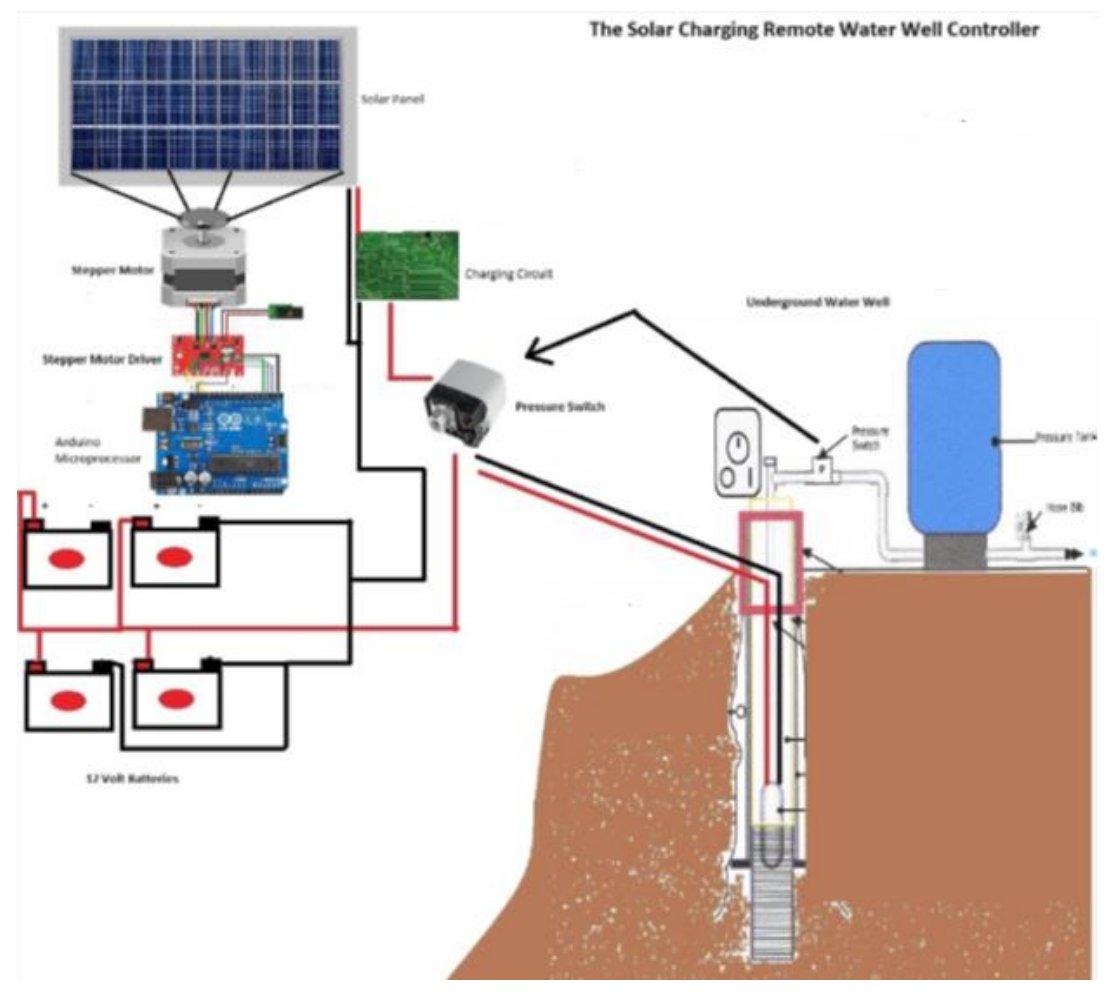

Figure 8: Solar Powered Water Well

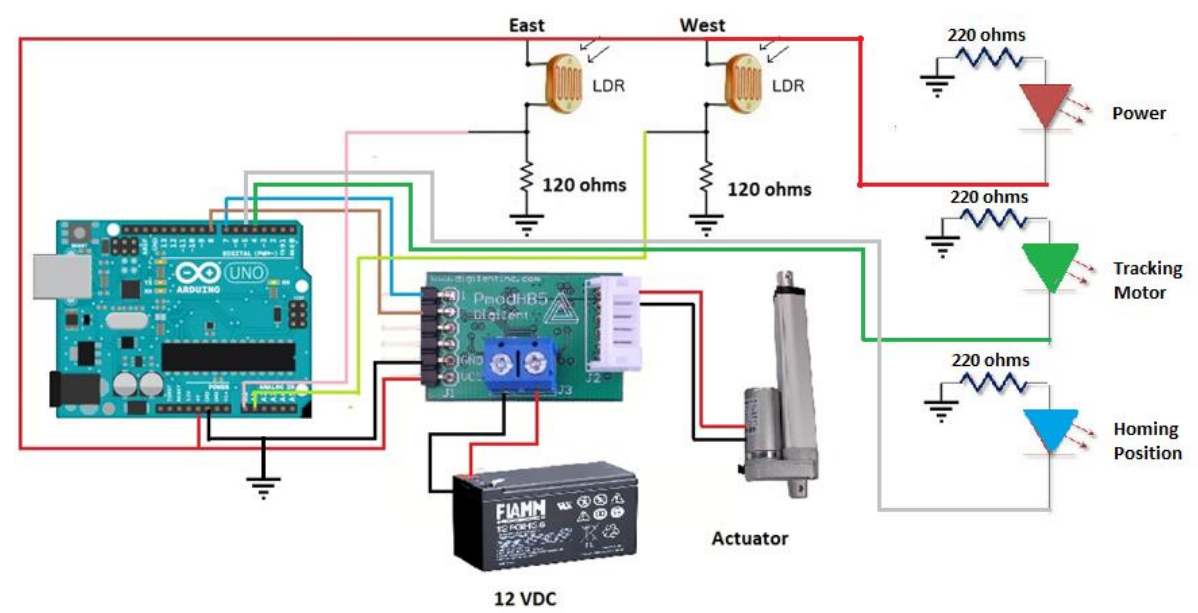

Figure 9: Circuit for Solar Powered Water Well

\section{Project 2}

Magneto Hydrodynamic Renewable Power 


\section{Objective}

This project considers the design and building of a device based on Magnetohydrodynamics using oceans saline water for generating electricity. Once this power is captured, it can be put to work in the isolated regions for a long-term use. Many literatures explain conversion of renewable sources such as: kinetic, potential, thermal, electromagnetic, and chemical to electrical energy. However, the tool designed in this project are novel and very attractive especially considering the fact that ocean has about 3.5\% saline composition. This project is intended to be used in saline oceans where there is a constant supply of salt water to feed the device and produce electricity.

\section{Project structure}

The Project has been divided into the following steps:
A. Mechanical Design (MHD generator, 3D Printed Channel, closed loop water flow)
B. Voltage Control Design (Microprocessor Control Digital Analog Convertor, DAC)
C. Data Acquisition \& Display Design (Microprocessor Analog Digital Convertor, $\mathrm{ADC})$
D. Communications Design (Microprocessor Interface w/ Laptop)
E. GUI Design (Java graphical User Interface w/ Micro Controller Using Java)

\section{System Requirements}

The water pump which controls the displacement of fluid through the channel runs from 0 Volts to 16 Volts. Normal operating conditions are 12 Volts. Fluid necessary in the system can be any impure water source, or distilled water w/ a saline compound such as Magnesium-Sulfate or Sodium-Chloride. Water pump design: Requires a variable voltage power supply or a 12 Volts source.

Arduino Uno and LCD are required for data acquisition of voltage at capacitors and battery. 
Several electronic components that make up the collection circuit, regulation circuit, boost circuit and charge controller circuit.

MDH channel and channel enclosure to protect from oxygen (corrosion).

Gas tank filled with 99\% to pure Argon gas, and tank regulator.

\section{Resources Requirements}

Fusion 360 by AutoCAD.

3DPrinter Manual.

Multisim simulation software for external circuitry design.

Gantt chart online software for project management.

Arduino Uno, Arduino IDE, AtMega328.

Test board and software.

Tektronix Oscilloscope.

Pasco Software, Pasco Air Link, Pasco Voltage/Current Sensor. Figure 10 displays the block diagram.

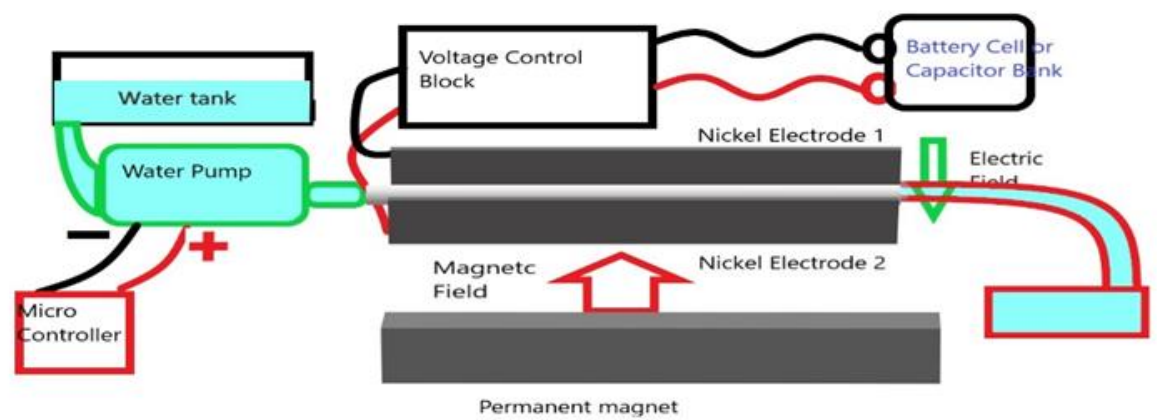

Figure 10: Magneto Hydrodynamic Renewable Power

\section{5- Assessments}

The following data are for REET senior project in different terms. The data cover ABET student's outcomes A through K. 
Outcome A: Rate the student's ability to select and apply traditional and contemporary disciplinary knowledge, techniques, skills, and (modern tools) to a product, process, or system.

Outcome B - Rate the students' ability to select and apply a knowledge of mathematics, science, and/or technology to solve a technical problem.

Outcome C - Rate the students' ability to evaluate a technical problem and to develop/conduct standard tests, measurements, and/or experiments to investigate the problem; analyze and interpret the results; and apply results to draw conclusions or make improvements.

Outcome D: Rate the student's ability to design systems components or Processes.

Outcome E: Rate the student's ability to function effectively as a member or leader on a technical team to accomplish a common goal.

Outcome F: Rate the students' ability to identify, analyze, and solve broadly defined technical problems.

Outcome G: In the following questions - rate the student's ability to apply Mitten, oral, and/or graphical communication in both technical and non-technical environments: and an ability to identify and use appropriate technical literature.

Outcome H: Rate the student's understanding of the need for and an ability to engage in selfdirected continuing professional development.

Outcome I: Rate the students understanding of and a commitment to address professional and ethical responsibilities including a respect for diversity.

Outcome J: Rate the student's understanding of technology's impacts on society and the world.

Outcome K: Rate the student's commitment to and demonstration of quality assurance, timeliness, and continuous improvement.

The sample size and the academic terms are listed in the Table 1.

\begin{tabular}{|c|c|}
\hline Session & Sample Size \\
\hline January 2019 & 35 \\
\hline May 2019 & 48 \\
\hline July 2019 & 13 \\
\hline September 2019 & 26 \\
\hline November 2019 & 6 \\
\hline
\end{tabular}


Table 1 Sample size

The collected data for A though $\mathrm{K}$ is displayed in the Figure 11. The benchmark is 2.5.

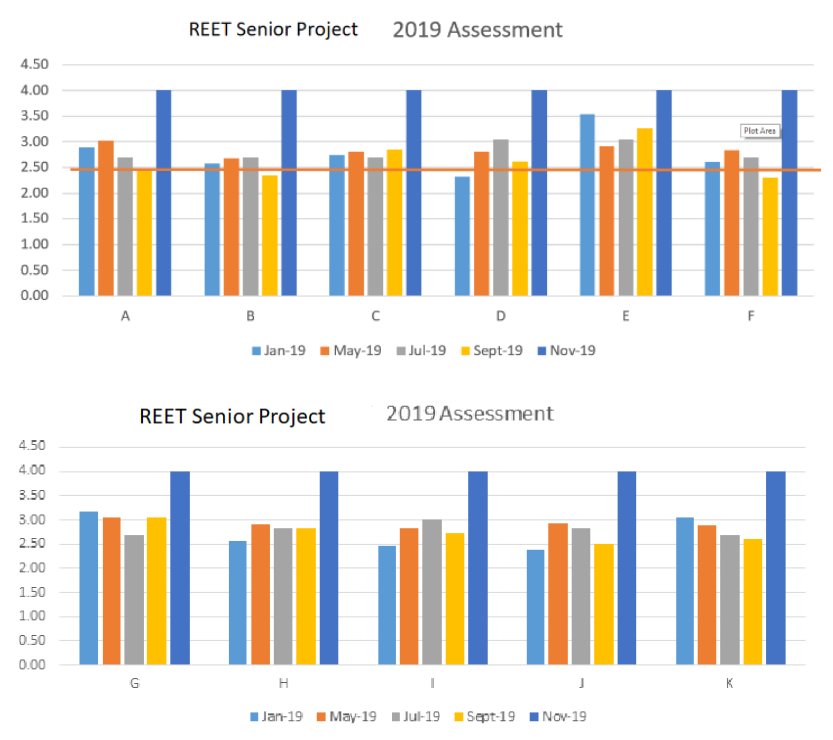

Figure 11 REET senior project data

By analyzing the assessment data, it seems students in the senior project have weaknesses in three major areas: Design, Mathematical modelling, Ethics

To improve design, mathematical modelling, and calculation, suggestion is to have one of the major weekly assignment be an Engineering Logbook. Every week students should submit their design, and calculation. For example, if students use SONAR in their project, in the engineering logbook they must write all calculations and how to measure distance or in the case of motor connection to micro-controller they must write in the logbook all calculations for the required current. Regarding ethics, in the course shell one module should be covered the engineering ethics specially IEEE Engineering Ethics.

\section{6- Summary}

REET program exposes students to the world of creating and implementing green technologies, such as wind, solar, photovoltaics, geothermal, and biomass power. A four-year degree with a specialization in renewable energy preparing student with technology skills that can put them to 
work in green technologies across three areas: Engineering Technology, Information Technology, and Software and Information Systems. Due to highly demand for renewable energy technology experts, the need to expand REET program is recommended.

In this paper author's experience in teaching courses in REET program, typical student senior projects, and job market forecast for this field discussed. The assessment data for the REET senior project was analyzed. Several recommendations for improving student's outcomes are suggested.

\section{References}

1. Alternative Energy Systems and Applications, by B. K. Hodge, 2010, John Wily \& Sons, Inc.

2. Electric Machinery Fundamentals, $5^{\text {th }}$, S. Chapman, 2011 McGraw-Hill

3. Power Electronics: Principles \& Applications, Jacob, J. Michael, 2002

4. Renewable Energy - Sustainable Energy Concepts for the Future, engenmayr, Roland and Bührke, Thomas, Eds., 2008.0 Verlag GmbH and Co. KGaA., Weinheim, Germany

5. Alternative Energy Systems in Building Design Gevorkian, P. (2010), New York: McGrawHill.

6. Techniques for a Wind Energy System Integration with an Islanded Microgrid Goyal, M., Fan, Y., Ghosh, A., \& Shahnia, F. (2016).. International Journal Of Emerging Electric Power Systems, 17(2), 191-203. doi:10.1515/ijeeps-2015-0139

7- Biofuels, Solar and Wind As Renewable Energy Systems: Benefits and Risks, Pimentel, D. (2008). [Dordrecht]: Springer.

8. Wind Energy Systems for Electric Power Generation, Stiebler, M. (2008), Berlin: Springer.

9. Reliability benefit of energy storage in wind integrated power system operation, Thapa, S., \& Karki, R. (2016).. IET Generation, Transmission \& Distribution, 10(3), 807-814. doi:10.1049/iet-gtd.2015.0162

10. Solar Energy Conversion, Crabtree, G. W., \& Lewis, N. S. (2007, March). Retrieved from AIP/Scitation: http://scitation.aip.org/content/aip/magazine/physicstoday/article/60/3/10.1063/1.271875 5

11. Installing and Maintaining a Home Solar Electric System. Energy.gov. (2016). Retrieved from Energy.gov: http://energy.gov/energysaver/installing-and-maintaining-home-solarelectric-system 
12. How do Photovoltaics Work? Knier, G. (2002). Retrieved from NASA:

http://science.nasa.gov/science-news/science-at-nasa/2002/solarcells/

13. Good to Green. Managing Business Risks and Opportunities in the Age of Environmental Awareness,1st Edition, John-David Phyper and Paul MacLean

2009.0 John Wiley \& Sons

14. Making Sustainability Work: Best Practices in Managing and Measuring Corporate Social, Environmental, and Economic Impacts, Marc J. Epstein

2008.0 Greenleaf Publishing 